\title{
Management of Okra Yellow Vein Mosaic Virus (OYVMV) Through Selected Insecticides and Light Reflecting Colored Mulches
}

\author{
Md. Belal Hossain, Suraiya Jitu, Sanjana Akter, and Md. Ariful Islam
}

\section{ABSTRACT}

\begin{abstract}
A field experiment was conducted to evaluate the effect of light reflecting colored mulches and only one time spraying with selected insecticides to control the insect vector of Okra Yellow Vein Mosaic Virus (OYVMV) whitefly (Bemisia tabaci) at the central farm of Sher-e-Bangla Agricultural University, Dhaka-1207. The experiment was carried out in three blocks layouted with RCBD comprising eight treatments viz. T0 (control/no spray), T1 (1 time spray with imitaf), T2 (1 time spray with protect), T3 (1 time spray with tiddo plus), T4 (1 time spray with terbine), T5 (light reflecting silver color mulch), T6 (light reflecting red color mulch) and T7 (light reflecting black color mulch) with three replications. The mulches were used before sowing and insecticides were sprayed at 30 DAS. It was observed that among the light reflecting colored mulches, the lowest disease incidence $(11.48 \%)$ was recorded in the plots which mulched with red color mulch (T6). Among the insecticides, the lowest disease incidence (30.17\%) was recorded in plots that was sprayed with terbine (one time). Yield and yield contributing characters, morphological and physiological features of okra plant that changes due to disease infection which cause damages in okra production and reduce the fruit quality as well as market value was also the part of this study. Yield and yield contributing characters showed significant variance among the selected treatments. In the relationship study, it was noticed that the yield and plant height was showed negative relationship with disease incidence. However, considering all measuring parameters, spraying with terbine (one time) and used red color mulch may be recommended as good management approaches that will give higher okra production and lower disease incidence of Okra Yellow Vein Mosaic Virus (OYVMV).
\end{abstract}

Keywords: Okra, OYVMV, Whitefly, Insecticides, Light reflecting color mulches.
Submitted : February 12, 2021

Published : February 24, 2021

ISSN: $2684-1827$

DOI: $10.24018 /$ ejfood.2021.3.1.245

\section{Md. Belal Hossain*}

Professor, Department of Plant Pathology, Sher-e-Bangla Agricultural University, Bangladesh.

(e-mail: dr.mbhossain@sau.edu.bd)

Suraiya Jitu

MS students, Department of Plant Pathology, Sher-e-Bangla Agricultural University, Bangladesh.

Sanjana Akter

MS students, Department of Plant Pathology, Sher-e-Bangla Agricultural University, Bangladesh.

Md. Ariful Islam

MS students, Department of Plant Pathology, Sher-e-Bangla Agricultural University, Bangladesh.

*Corresponding Author

\section{INTRODUCTION}

Okra commonly known as Lady's finger is originated from West Africa as an annual vegetable that grown from seed in tropical and subtropical region of the world [1]. In Asian countries, it's grown throughout the year and has great commercial demand due to its high nutritional and medicinal values. It is a very common and well distributed over the Indian subcontinent and East Asia [2]. Though it is popular vegetable, it is mainly grown during the summer season. It is also grown in winter season in Bangladesh with very poor land coverage. In Bangladesh, the annual okra production is 54.901 thousand metric tons from 28.106 thousand hectares of land [3].

The yield and quality of okra depend on several factors like disease, insects, soils and climatic conditions. Among the factors responsible for limiting the yield and quality of okra, Yellow Vein Mosaic Virus (YVMV) is the most important ones [4]. Okra Yellow Vein Mosaic Virus (OYVMV), transmitted by the whitefly [5]. Among several diseases, yellow vein mosaic disease is the most severe one affecting the quantity and quality of the fruits [6] and always been a serious problem in okra production and yield reductions of 20-50\% have occurred. This loss may increase up to $90 \%$ [7]. The virus seems to attack okra plants in any stage of plant growth, spreads quickly in the field and adversely affects the growth and yield contributing characters due to remarkable alternation in cellular components of the infected plants [8], [9].

There is no effective control measure against the virus in the field once it is established. Controlling its vector by spraying insecticide may be a method of controlling this disease or it may be used as a component of integrated control. The application of insecticides from date of seed sowing upto flowering might have meaningful effect to reduce the early population buildup of whitefly. The variabilities of okra varieties in relation to the population build-up of whitefly under natural conditions have been reported by Begum [10].

Some insecticides and plant extracts have also been evaluated against the whitefly transmitting the virus in okra field [11], [12] and [13]. Many researches have been done to assess the impact of different mulch materials on the disease 
incidence of OYVMV. Mulching conserve soil moisture, controls weed and whitefly population through reflection of light. Plastic mulch induced the highest yield of okra plants and less disease incidence was observed. [14].

Considering the above mentioned factors the research experiment was to use light reflecting plastic colored mulches and to spray selected insecticides only one time for management of OYVMV by controlling the insect vectors whitefly.

\section{Methodology}

A. Identification of Disease Symptoms and Estimation of Disease Incidence (\%) of Okra Yellow Vein Mosaic Virus (OYVMV)

Based on studying of typical symptoms of okra yellow vein mosaic virus tested of okra plant were described by researchers [15], [10], [12]. The okra plants were observed regularly until harvest. And the symptom was recorded found in the okra plants. The growth stage of the okra plants was categorized as follows:

1) Early stage -5 weeks after seed sowing.

2) Mid stage - 5 weeks after early stage, and.

3) Late stage - after mid stage up to harvest.

4) The disease incidence was expressed in percentage on the basis of crop growth stages as well as average of three stages. The percent of disease incidence was calculated by using the following formula:

$$
\text { Disease incidence }(\%)=\frac{X 1}{X} \times 100
$$

where

$\mathrm{X}=$ Total number of plants.

$\mathrm{X} 1=$ Number of infected plants.

\section{B. Parameters Assessed}

In this study different kind of measures were taken. The following parameters were documented:

1. Disease incidence (\%).

2. Number of leaves per plant.

3. Number of infected leaves per plant.

4. Study of insect vectors association (vectors/leaf).

5. Number of flowers per plant.

6. Number of fruits per plant.

7. Fruit weight $(\mathrm{Kg})$.

8. Yield $(\mathrm{Kg})$.

9. Plant height $(\mathrm{cm})$.

10. Root length $(\mathrm{cm})$.

\section{Spraying Insecticides}

Spraying was done with selected insecticides at 30 DAS. Water was also applied at the 30 DAS. The insecticides doses were given below:

T1- Imitaf 20 SL@ $2.5 \mathrm{ml} / 10$ liters water.

T2- Protect 50 SG@2.5ml/L water.

T3- Tiddo Plus70 WDG @ 0.2g/L water.

T4- Terbine 75 WDG @0.2 g/L Water.

\section{Statistical Analysis}

The data were analyzed by using computer based software Statistix-10 and performed the analysis of variance
(ANOVA) for proper interpretation. The mean value was compared according to CV value and LSD at 5\% level of significance. The analyzed data are presented in tabular and graphical form.

\section{RESUlt AND DisCUSSION}

A. Effect of Selected Treatments on Disease Incidence of Okra Yellow Vein Mosaic Virus (OYVMV)

In this study, four selected insecticides and three light reflecting colored mulches were used to manage the Okra yellow vein mosaic virus via controlling the insect vectors white fly. The disease incidence (\%) was estimated at 40, 60 and $80 \mathrm{DAS}$. It was noticed that the disease incidence (\%) due to Okra Yellow Vein Mosaic Virus was varied in all treatments plots in each of observation. Among the treatments, the lowest disease incidence $(\%)$ was recorded in the plots which covered with red color mulch. This treatment was combined with sowing time, it gave the best result in controlling the insect vectors white fly. It was also noticed that among the selected insecticides, Imitaf and Terbine also showed the best performance with combination of sowing time in controlling the insect vectors whitefly (Table I). The result of the present study is in accordance with the results of Sayed et al. [16] when they used imidacloprid as single spray combined with mulch gave best result. This is due to presence of lower number of insect vectors white fly. So considering the economic condition/cost-benefit ratio, red color mulch gave the best result among the selected treatments. The present study is also accordance with the result of Kareem, (2012) [14] they found that Plastic mulch produced the highest yield and the mulches especially plastic are effective in controlling okra mosaic virus (OMV).

TABLE I. EFFICACY OF SELECTED INSECTICIDES AND LIGHT REFLECTING COLORED MULCHES ON THE DISEASE INCIDENCE OF OKRA YELLOW VEIN MOSAIC VIRUS (OYVMV) AT 40, 60 AND 80 DAS

\begin{tabular}{cccc}
\hline \multirow{2}{*}{ Treatment } & \multicolumn{3}{c}{ Disease incidence (\%) } \\
\cline { 2 - 4 } & at 40 DAS & at 60 DAS & at 80 DAS \\
\hline T0 = control (no spray, no & $9.73 \mathrm{a}$ & $31.22 \mathrm{a}$ & $9.73 \mathrm{a}$ \\
mulch) & $0.0 \mathrm{~d}$ & $15.01 \mathrm{c}$ & $32.21 \mathrm{~b}$ \\
T1 = 1 spray of Imitaf & $3.80 \mathrm{~b}$ & $14.81 \mathrm{c}$ & $30.72 \mathrm{c}$ \\
T2 = 1 spray of Protect & $2.38 \mathrm{~b}$ & $18.55 \mathrm{~b}$ & $34.45 \mathrm{~b}$ \\
T3 = 1 Spray of Tiddo Plus & $6.18 \mathrm{c}$ & $17.92 \mathrm{~b}$ & $30.17 \mathrm{c}$ \\
T4 = 1 Spray of Terbine & $0 \mathrm{~d}$ & $3.62 \mathrm{~d}$ & $12.72 \mathrm{~d}$ \\
T5 = Silver color mulch & $0 \mathrm{~d}$ & $4.89 \mathrm{~d}$ & $11.48 \mathrm{~d}$ \\
T6 = Red color mulches & $0 \mathrm{~d}$ & $7.02 \mathrm{e}$ & $16.83 \mathrm{e}$ \\
T7 = Black color mulches & 5.38 & 30.74 & 23.28 \\
CV\% & 3.37 & 5.39 & 5.39 \\
LSD $(0.05)$ & & &
\end{tabular}

\section{B. Effect of Selected Treatment on Whitefly Association per Leaf of Okra Plant}

The minimum number of whitefly $(4.00,4.33,5.00)$ per leaf was recorded in the plants from the plots which covered with light reflecting colored mulches and one time sprayed with Terbine (T4). The maximum number of whitefly per leaf was recorded in control plants. So, light reflecting silver color mulching combined with early sowing was unfavorable for whitefly infestation. Results of white fly association are presented in (Table II). Early infection of insect vectors whitefly causes drastic reduction of all the growth contributing character of all the okra varieties. The extent of 
damage in different growth contributing characters was largely dependent upon the stage of infection of (OYVMV) via insect vectors, condition of growing seedlings and okra varieties. Ojiako [17] concluded that okra cultivated with plastic mulch reduced insect pests and produced healthier plants.

TABLE II: EFFICACY OF SELECTED INSECTICIDES AND LIGHT REFLECTING COLORED MULCHES ON WHITEFLY ASSOCIATION PER LEAF

\begin{tabular}{cc}
\hline Treatment & Whitefly association/leaf \\
\hline T0 = control (no spray, no mulch) & $12.00 \mathrm{a}$ \\
T1 =1 spray of Imitaf & $6.33 \mathrm{c}$ \\
T2 $=1$ spray of Protect & $7.35 \mathrm{~b}$ \\
T3 =1 Spray of Tiddo & $6.35 \mathrm{c}$ \\
T4 =1 Spray of Tebrine & $5.00 \mathrm{~d}$ \\
T5 $=$ Silver color mulch & $4.33 \mathrm{~d}$ \\
T6 $=$ Red color mulches & $4.00 \mathrm{~d}$ \\
T7 = Black color mulches & $5.00 \mathrm{~d}$ \\
CV\% & 2.35 \\
LSD $(0.05)$ & 0.96 \\
\hline
\end{tabular}

C. Effect of Selected Treatments on Morphological Features of Okra Plant against Okra Yellow Vein Mosaic Virus (OYVMV)

Among the treatments, the maximum number of leaves, flowers, fruits per plant was recorded in the plots which covered with light reflecting silver color mulching (T5) and red color mulching (T6) and the plots sprayed with Terbine (T4). The minimum number of leaves, flowers, fruits per plant was recorded in control condition (T0). The results are presented in (Table III). So, light reflecting silver color mulching and red color mulching combined with early sowing was favorable for okra production. Khan [18] studied that late sowing gave less plant population and gave less leaf, flower and fruits.

TABLE III: EFFICACY OF SELECTED TREATMENTS AND LIGHT REFLECTING COLORED MULCHES ON THE LEAF NUMBER, FlOWER AND FRUIT PER

\begin{tabular}{|c|c|c|c|}
\hline Treatment & $\begin{array}{c}\text { No. of } \\
\text { leaf/plant }\end{array}$ & $\begin{array}{c}\text { No. of } \\
\text { flower/plant }\end{array}$ & $\begin{array}{c}\text { No. of } \\
\text { fruit/plant }\end{array}$ \\
\hline $\begin{array}{l}\mathrm{T} 0=\text { control (no } \\
\text { spray, no mulch) }\end{array}$ & $10.24 \mathrm{~d}$ & $15.51 \mathrm{~b}$ & $12.179 \mathrm{~d}$ \\
\hline $\begin{array}{c}\mathrm{T} 1=1 \text { spray of } \\
\text { Imitaf }\end{array}$ & $12.24 \mathrm{~cd}$ & $17.84 \mathrm{ab}$ & $14.18 \mathrm{c}$ \\
\hline $\begin{array}{l}\mathrm{T} 2=1 \text { spray of } \\
\text { Protect }\end{array}$ & $15.10 \mathrm{bc}$ & $19.00 \mathrm{ab}$ & $15.23 \mathrm{~b}$ \\
\hline $\begin{array}{l}\text { T3 = 1spray of } \\
\text { Tiddo Plus }\end{array}$ & $19.16 \mathrm{abc}$ & $20.64 \mathrm{ab}$ & $17.67 \mathrm{~b}$ \\
\hline $\begin{array}{c}\text { T4 = } 1 \text { spray of } \\
\text { Terbine }\end{array}$ & $21.15 \mathrm{a}$ & $22.98 \mathrm{a}$ & $20.00 \mathrm{a}$ \\
\hline $\begin{aligned} \mathrm{T} 5= & \text { Silver color } \\
& \text { mulch }\end{aligned}$ & $19.60 \mathrm{abc}$ & $17.00 \mathrm{~b}$ & $14.78 \mathrm{c}$ \\
\hline $\begin{array}{c}\mathrm{T} 6=\text { Red color } \\
\text { mulches }\end{array}$ & $20.56 \mathrm{ab}$ & $18.18 \mathrm{~b}$ & $15.49 \mathrm{c}$ \\
\hline $\begin{array}{c}\mathrm{T} 7=\text { Black color } \\
\text { mulches }\end{array}$ & $19.94 \mathrm{abc}$ & $17.51 \mathrm{ab}$ & $14.49 \mathrm{c}$ \\
\hline $\mathrm{CV} \%$ & 10.18 & 10.18 & 12.85 \\
\hline LSD (0.05) & 3.14 & 3.36 & 3.54 \\
\hline
\end{tabular}

D. Effect of Different Treatments on Yield and Yield Contributing Characters of Okra Plant

The highest yield per plant and plot was recorded in the plots which covered with light reflecting silver color mulching (T5) and red color mulching (T6). The highest yield per plant and plot was also recorded in the plots which covered with light reflecting black color mulching (T7). Considering the economic condition/cost-benefit ratio maintaining sowing time along with three different types of mulch gave the best result regarding in yield and yield contributing characters. Among the insecticides, Terbine (T4) also gave highest yield. Where the lowest yield per plant and plot was recorded in control condition (T0). Almost same results were found in recent study that was conducted by Sayed [16]. There is no more previous report over yield of okra against OYVMV in our country. The results are presented in (Table IV).

TABLE IV: EFFICACY OF SELECTED TREATMENTS AND LIGHT REFLECTING COLORED MULCHES ON YIELD

\begin{tabular}{ccc}
\hline Treatment & $\begin{array}{c}\text { Yield per plant } \\
(\mathrm{kg})\end{array}$ & Yield per plot $(\mathrm{kg})$ \\
\hline $\mathrm{T} 0=$ control (no spray, no & $0.40 \mathrm{~d}$ & $1.23 \mathrm{~d}$ \\
mulch) & $0.66 \mathrm{c}$ & $2.54 \mathrm{c}$ \\
T1 = 1 spray of Imitaf & $0.61 \mathrm{c}$ & $2.83 \mathrm{c}$ \\
T2 = 1 spray of Protect & $0.72 \mathrm{~b}$ & $3.09 \mathrm{~b}$ \\
T3 = 1 spray of Tiddo Plus & $0.82 \mathrm{~b}$ & $3.18 \mathrm{~b}$ \\
T4 = 1spray of Terbine & $0.81 \mathrm{a}$ & $4.08 \mathrm{a}$ \\
T5 = silver color mulch & $0.92 \mathrm{a}$ & $4.85 \mathrm{a}$ \\
T6 = red color mulches & $0.87 \mathrm{a}$ & $4.71 \mathrm{a}$ \\
T7 = black color mulches & 18.28 & 23.35 \\
CV\% & 0.023 & 1.37 \\
LSD $(0.05)$ & & \\
\hline
\end{tabular}

E. Effect of Different Sowing Time and Treatments on Plant Height and Root Length of Okra Plant

The maximum plant height and root length was recorded in the plots which covered with light reflecting silver color mulching (T5), red color mulching (T6) and black color mulching (T7). The maximum Plant height and root length was also recorded in the plots which sprayed with insecticides Terbine (T4), Tiddo plus (T3) and Imitaf (T1). The minimum plant height and root length was recorded in control condition (T0). The results are presented in table 10. So, light reflecting silver, red, black color mulching was favorable for maximum plant height. The result is accordance with Khan [18] and he studied that late sowing gave minimum plant height.

TABLE V: EFFICACY OF SELECTED INSECTICIDES AND LIGHT REFLECTING COLORED MULChES ON Plant HeiGHT (CM) AND ROOT LENGTH (CM)

\begin{tabular}{ccc}
\hline Treatment & $\begin{array}{c}\text { Plant height } \\
(\mathrm{cm})\end{array}$ & Root length $(\mathrm{cm})$ \\
\hline T0 = control (no spray, no & $74.13 \mathrm{c}$ & $18.56 \mathrm{~d}$ \\
mulch) & $89.08 \mathrm{~b}$ & $19.73 \mathrm{c}$ \\
T1 = 1 spray of Imitaf & $77.97 \mathrm{c}$ & $19.51 \mathrm{c}$ \\
T2 = 1 spray of Protect & $94.36 \mathrm{a}$ & $22.00 \mathrm{~b}$ \\
T3 = 1 spray of Tiddo Plus & $95.35 \mathrm{a}$ & $23.93 \mathrm{~b}$ \\
T4 = 1spray of Terbine & $89.65 \mathrm{~b}$ & $24.13 \mathrm{a}$ \\
T5 = silver color mulch & $95.86 \mathrm{a}$ & $24.11 \mathrm{a}$ \\
T6 = red color mulches & $92.78 \mathrm{a}$ & $23.62 \mathrm{~b}$ \\
T7 = black color mulches & 10.89 & 12.23 \\
CV\% & 7.88 & 4.77 \\
\hline LSD $(0.05)$ & &
\end{tabular}

F. Effect of Different Treatments in Relationship between Disease Incidence (\%) and Yield ( $\mathrm{kg} /$ plot)

The relationship between disease incidence and yield performance of okra plants was also studied. From the study it was revealed that there is inverse relation between disease incidence and yield. When disease incidence is increased, the yield of okra is also decreased. It was evident from the Fig. 1. 


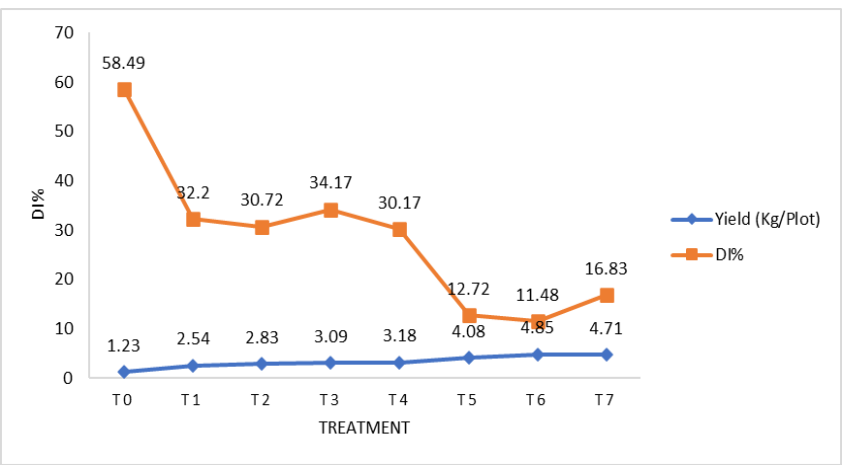

Fig. 1. Relationship between disease incidence (\%), different treatments and yield (kg/plot).

G. Effect of Different Treatments in Relationship between Disease Incidence (\%) and Yield (t/ha)

The relationship between disease incidence and yield performance of okra plants was also studied. From the study it was revealed that there is inverse relation between disease incidence and yield. When disease incidence is increased, the yield of okra is also decreased. It was evident from the Fig. 2.

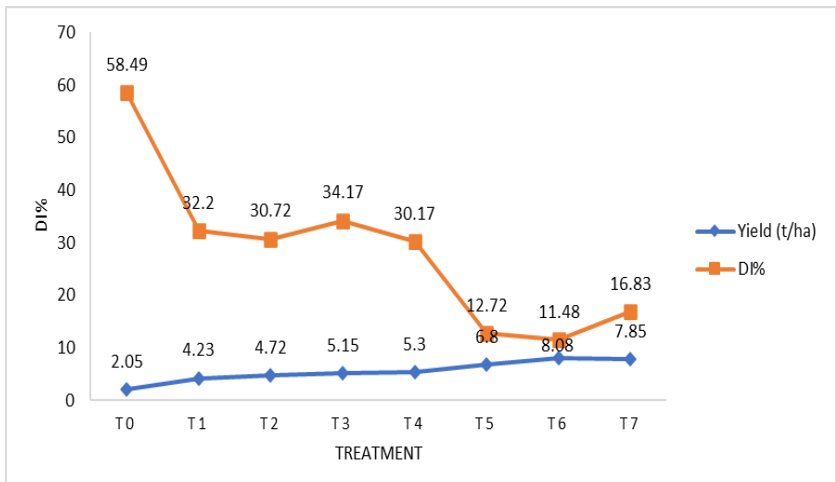

Fig. 2. Relationship between disease incidence (\%), different treatments and yield (t/ha).

\section{H. Effect of Different Treatments in Relationship between Disease Incidence (\%) and Plant Height (cm)}

The relationship between disease incidence and plant height of okra plants was also studied. From the study it was revealed that there is inverse relation between disease incidence and plant height. When disease incidence is increased, the plant height of okra is also decreased. It was evident from the Fig. 3.

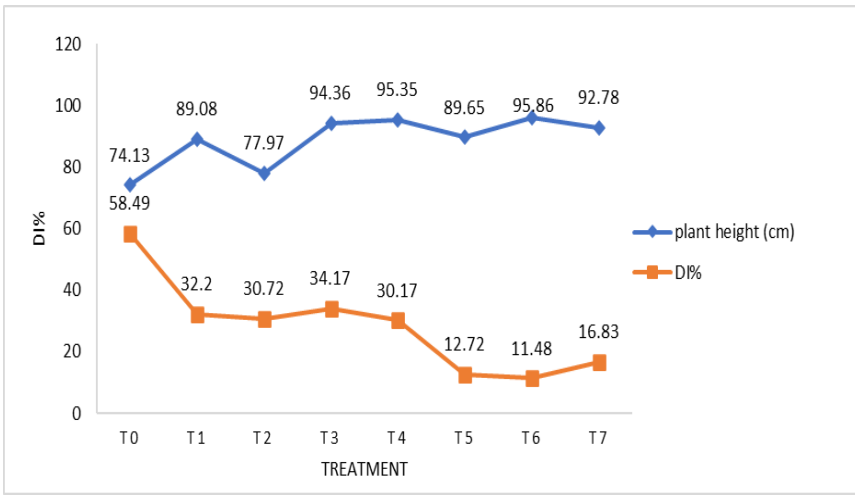

Fig. 3. Relationship between disease incidence (\%), different treatments and plant height $(\mathrm{cm})$.

\section{Conclusion}

From the study, it may conclude that among the selected treatments, the lowest disease incidence was estimated from the plots that covered with red colored mulch and one time sprayed with insecticide, Terbine. The highest disease incidence was recorded in control condition. The highest number of leaves, flowers and fruits per plant was recorded in the plots that covered with red color mulch (T6) and sprayed one time with Terbine (T4). Yield and yield contributing characters showed significant variation among the selected treatments. The highest yield per plant and plot was obtained in the plots that covered with red colored mulch (T6) and sprayed one time with Terbine (T4). In the relationship study, it was noticed that the yield and plant height showed negative relationship with disease incidence. The yield and plant height decreased with the increased of percent disease. From the study, it may conclude that among the treatments, the red color mulch and one time spray with Terbine gave the better performance in controlling the insect vectors whitefly. However, considering all measuring parameters, for cultivation of okra one time spray with Terbine and used red color mulch may be recommended as management approaches of Okra Yellow Vein Mosaic Virus (OYVMV).

\section{ACKNOWLEDGMENT}

The authors thank to University Grand Commission (UGC) for financial support and Sher-e-Bangla Agricultural University (SAU), Dhaka, Bangladesh for technical support to conduct the research work successfully.

\section{REFERENCES}

[1] M.R. Thakur and S.K. Arora. (1986). Bhendi, In- Vegetables CropinIndia (T.K. Bose and M.G. Som.Eds.). Naya Prakash, 200, Bidhan Sarani, Calcata, pp 613-622.

[2] M. M. Rashid (1999). Shabjibiggayan (In Bengali). Rashid Publishing House, 94, Old DOHS, Dhaka-1206. pp 49.

[3] BBS. 2017. Year Book of Agricultural Statistics of Bangladesh, 20152016, Statistics Division, Ministry of Planning, Dhaka.

[4] K.S.M. Sastry and S.J. Singh. (1974). Effect of yellow vein mosaic virus infection on growth and yield of okra crop. Indian Phytopathology, 27(3), pp 294-297.

[5] M. Ali, M. Z. Hossain and N. C. Saker. (2000). Inheritance of Yellow vein mosaic virus (YVMV) tolerance in a cultivar of okra (Abelmoschus esculentus L. Moench). Euphytica, 11(3), pp 205-209.

[6] B.N. Uppal, P.M. Verma and S.P. Capoor, (1940). Yellow mosaic of bhendi. Current Science, 9, pp 227-228.

[7] N. Pullaiah, T.B. Reddy, G.J. Moses, B.M, Reddy and D.R. Reddy. (1998). Inheritance of resistance to yellow vein mosaic virus in okra (Abelmoschus esculentus (L.) Moench). Ind. J. Gene. Plant Breeding, 58(3), pp 349-352.

[8] M. D. Hossain, M. B. Meah and G. M. M. Rahman (1998). Reaction of okra variety to Yellow vein mosaic virus and biochemical changes in its infected leaf constituents. Bangladesh Journal of Plant Pathology, 14(1-2), pp 29-32.

[9] U. C. Sarma, K. N. Bhagabati and C. R. Sarkar. (1995). Effect of Yellow vein mosaic virus infection on some chemical constituents of bhendi (Abelmoschus esculentus L. Moench). Indian Journal of Virology, 11(1), pp 81-83.

[10] M. A. Begum. (2002). Prevalence and spread of Okra yellow vein clearing mosaic virus in the field and its impact on growth and yield of okra. MS Thesis. Department of Plant Pathology. BSMRAU.

[11] Anonymous, (1993). Control of yellow mosaic virus of Lady's finger. MS Thesis. Department of Plant Pathology. Bangladesh Agricultural University, Mymensingh. 
[12] A. B. M. S. Hossain (1998). Effect of intercropping on incidence of okra mosaic disease. MS thesis. Department of Plant Pathology, Bangladesh Agricultural University, Mymensingh.

[13] M. A. S. Miah. (1988). Effect of Date of planting and insecticidal spray on the control of yellow vein mosaic disease of Lady's finger (Hibiscus esculentus L.). Abstracts of Thesis (1966-1990). Department of Plant Pathology, Bangladesh Agricultural University, Mymensingh-2202, March, 1991. pp 79.

[14] K. T. Kareem, O.O. Alamu, R.K. Egberrongbe and O. Arogundade. (2012). Effect of different materials on the incidence and severity of okra mosaic virus (OMV) in okra. Journal ofApplied Horticulture, 14(1), pp 51-55.

[15] S. P. Capoor and P. M. Varma. (1950). Yellow vein mosaic of Hibiscus esculentus L. Indian Journal of Agricultural Science, 20, pp 217-230.

[16] S.M. Sayed, M. Hossain and A. A. Khan. (2018). Effect of insecticide and mulching on Yellow vein mosaic of Lady"s finger. Bangladesh Horticulture, 18(1\&2), pp 65-68.

[17] F. O. Ojiako, A. E. Ibe, E. C. Ogu and Okonkwo, C. C. (2018). Effect of varieties and mulch types on foliar insect pests of okra [Abelmoschus Esculentus L. (Moench)] in a humid tropical environment. Agrosearch, 18 (2), pp 38-58.

[18] H. Khan, M. Khan. K. Rasul and A. Bhatti. (2000). Response of okra Abelmoschus Esculentus L.to three different sowing dates in the mid hill of swat valley. P. J. of Bio. Sci, 12(3), pp 2010-2012.

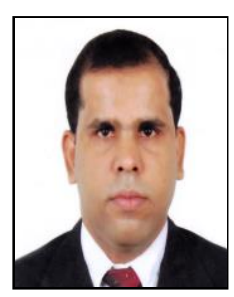

Dr. Md. Belal Hossain was born in a respected muslim family under Upazilla and District Thakurgaon on $21^{\text {st }}$ August,1980 in Bangladesh. He has completed B.Sc.Ag(Hons.) and MS in Plant Pathology from Sher-e-Bangla Agricultural University, Dhaka, Bangladesh and obtained $1^{\text {st }}$ class and CGPA 3.73 out of 4 scale respectively. After completion his MS Degree he joined as a Lecturer in the same Department and University in 2006. After completion his lecturer tenure he has got promotion as Assistant Professor in 2008. He has got CEMB-TWAS Postgraduate Fellowship' 2008 for his $\mathrm{PhD}$ program and he has successfully completed his $\mathrm{PhD}$ in Molecular Biology in 2014. After completion his $\mathrm{PhD}$ he was backed in Bangladesh and joined the same Department and University. He got promotion as Associate Professor in 2014 and Professor in 2018. Now he is working as Professor in the Department of Plant Pathology, Sher-e-Bangla Agricultural University, Dhaka, Bangladesh. He has attended many international seminar, symposium, workshop and conference. He has published many scientific papers in different national and international peerreview indexing and impact factor journals. He is also the editor and reviewer of national and international peer-review journals. 